IFAS Extension

\title{
A Mealybug Phenacoccus multicerarii Granara de Willink (Hemiptera: Pseudococcidae) ${ }^{1}$
}

\author{
lan Stocks ${ }^{2}$
}

\section{Introduction}

Florida Department of Agriculture and Consumer Services, Division of Plant Industry (FDACS-DPI) inspector Lisa Hassell collected the mealybug Phenacoccus multicerarii, a new continental record, from a retail nursery in Fernandina Beach (Nassau County, on 15 June 2011). On a return visit to the store, the mealybug was observed in high numbers on numerous host plants. On 28 June 2011, an additional find was made at a nursery in Apopka that had exchanged plant material with the nursery in Jacksonville. No further infestations were reported until October 2012, when a heavy infestation was discovered on a residential planting of Plectranthus scutellarioides (L.) Dodd (= Solenostemon scutellarioides, common coleus) in Cooper City (Broward County). This mealybug was described in 2007 from a

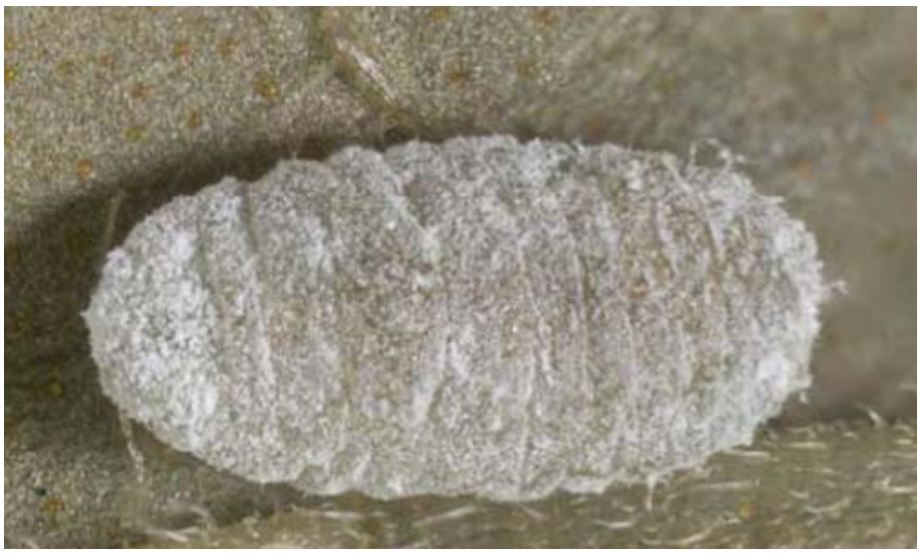

Figure 1. Adult female Phenacoccus multicerarii on a leaf.

Credits: I.C. Stocks, Florida Department of Agriculture and Consumer Services, Division of Plant Industry

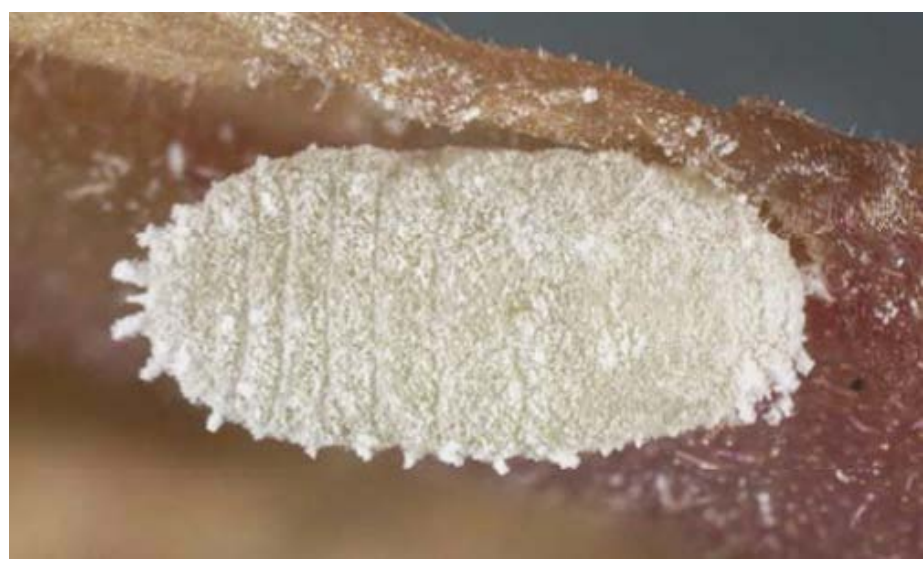

Figure 2. Adult female Phenacoccus multicerarii on a leaf.

Credits: I.C. Stocks, Florida Department of Agriculture and Consumer Services, Division of Plant Industry

sample collected in Caracas, Venezuela, in 1949 from an unknown host (Granara de Willink and Szumik 2007).

\section{Distribution}

Venezuela; USA: Florida

\section{Description}

Phenacoccus multicerarii is a relatively large mealybug, with adult females oval in shape and measuring 3.5 to $4 \mathrm{~mm}$ ( $\sim .15 \mathrm{in}$ ) long and $2 \mathrm{~mm}$ (0.08 in) wide. The general body color is yellowish to light grey with a conspicuous dusting of powdery white wax (). In the live specimens available for observation, the lateral and terminal wax filaments, which are commonly observed in many mealybug species, are only

1. This document is EENY-550, one of a series of the Entomology and Nematology Department, Florida Cooperative Extension Service, Institute of Food and Agricultural Sciences, University of Florida. Original publication date April 2013. Visit the EDIS website at http://edis.ifas.ufl.edu.

2. Ian Stocks, taxonomic entomologist, Florida Department of Agriculture and Consumer Services, Division of Plant Industry, and affiliate faculty, Entomology and Nematology Department, Institute of Food and Agricultural Sciences, University of Florida, Gainesville, FL 32611.

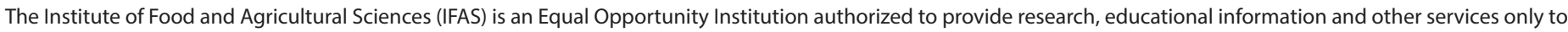

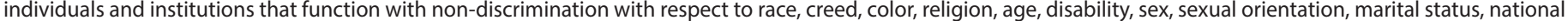
origin, political opinions or affiliations. U.S. Department of Agriculture, Cooperative Extension Service, University of Florida, IFAS, Florida A\&M University Cooperative Extension Program, and Boards of County Commissioners Cooperating. Nick T. Place, Dean 
weakly developed or are absent. Adult females produce a large ovisac of cottony and sticky wax that is attached to the posterior of the female (), and the eggs inside the ovisac are bright yellow. In general appearance and size, this species is similar to the common mealybug species Phenacoccus madeirensis Green, the madeira mealybug, and Phenacoccus solenopsis Tinsley, the solenopsis mealybug. Positive identification requires slide-mounting of the specimen. In the Apopka nursery infestation, both the madeira mealybug and Planococcus citri (Risso), the citrus mealybug, were also found.

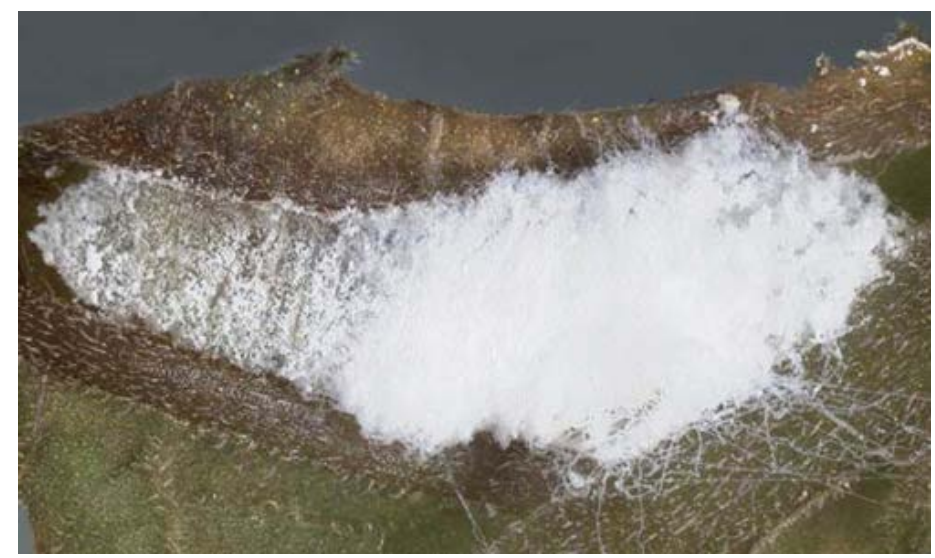

Figure 3. Adult female Phenacoccus multicerarii with ovisac on a leaf. Credits: I.C. Stocks, Florida Department of Agriculture and Consumer Services, Division of Plant Industry

\section{Biology}

The series of collections made at the Fernandina Beach nursery and the residential planting in Cooper City revealed a population with all life stages present. Numerous females had fully developed ovisacs filled with eggs, and both immature and adult males were found.

\section{Hosts}

In Florida, the following host plants were documented:

Asteraceae: Pseudognaphalium obtusifolium (L.) Hilliard and Burtt, obtusifolium subsp.

Begoniaceae: Begonia sp.

Convolvulaceae: Ipomoea batatas (L.) Lam.

Dryopteridaceae: Polystichum sp.; Cyrtomium falcatum (L.

f.) C. Presl

Ericaceae: Rhododendron sp.

Labiatae: Plectranthus scutellarioides (L.) Codd

Liliaceae: Hosta sp.; Aloe vera (L.) Burm. f.

Melastomataceae: Medinilla magnifica Lindl.
Moraceae: Ficus pumila L.

Primulaceae: Lysimachia nummularia L.

Saxifragaceae: Hydrangea sp.

Selaginellaceae: Selaginella uncinata (Desv. ex Poir.) Spring Thelypteridaceae: Thelypteris sp.

\section{Economic Importance}

The potential impact of this mealybug should it become established in the environs is unknown, but finding robust populations on several unrelated plant species suggests that it is potentially polyphagous. The genus Phenacoccus is very large and contains many species that are or have been highly destructive in various regions of the world. In general, all Phenacoccus species should be considered as high-risk for establishment.

\section{Selected References}

Granara de Willink MC, Szumik C. 2007. Phenacoccinae de Centro y Sudamérica (Hemiptera: Coccoidea: Pseudococcidae): Sistemática y Filogenia. Revista de la Sociedad Entomológica Argentina 66: 29-129. 